\title{
Search for Alkaloids on Callus Culture of Passiflora alata
}

\author{
Michelli Wesz Machado ${ }^{1}$, Carlos Stern Neto $^{1}$, Juliana Salgado ${ }^{1}$, Gilmar Zaffari ${ }^{1}$, \\ Andersson Barison ${ }^{2}$, Francinete Ramos Campos ${ }^{2}$, Yuri Eberlim de Corilo ${ }^{3}$, Marcos \\ Nogueira Eberlin $^{3}$ and Maique Weber Biavatti ${ }^{4 *}$ \\ ${ }^{I}$ Núcleo de Investigações Químico-Farmacêuticas; Universidade do Vale do Itajaí; Rua Uruguai, 458; 88302-202; \\ Itajaí - SC - Brasil. ${ }^{2}$ Departamento de Química, Universidade Federal do Paraná; 81531-99; Curitiba - PR - Brasil. \\ ${ }^{3}$ Instituto de Química; Universidade Estadual de Campinas; 13083-970; Campinas - SP - Brasil. ${ }^{4}$ Departamento de \\ Ciências Farmacêuticas; Universidade Federal de Santa Catarina; 88040-900; Florianópolis - SC - Brasil
}

\begin{abstract}
Preliminary work on Passiflora alata leaves failed to detect harmane alkaloids using LC. The aim of this work was to investigate the production of harmane alkaloids through the cell culture of $\mathrm{P}$. alata, inducing its precursor (Ltryptophan). The leaf explants presented satisfactory results after disinfection, and the callus formation was initiated in MS media with adequate quantities of phytohormones. Sixty days after inoculation, calli were inoculated in the optimized semi-solid MS media, with and without the addition of L-tryptophan (50, 100, $200 \mathrm{mg} / \mathrm{L})$ and kept in standard conditions for 90 days. Calli were collected on days 6, 16, 26, 36, and 90, followed by acid-base extraction, and analysed by LC. The results showed an absence of harmane, harmin, harmol, harmalol, and harmaline. With L-tryptophan feeding, two peaks were detected, collected and analysed through positive mode electrospray [ESI(+)-MS] and sequential analysis in tandem ESI(+)-MS/MS. The spectra obtained were very similar, with a repetition of the more intense ions, and consecutive loss of $68 \mathrm{Da}$ units, attributed to the heterocycle pyrazole. It appeared that this transformation was not related to any enzymatic pathway previously described for the plant from L-tryptophan, and the biosynthesis of $\beta$-carboline alkaloids in callus culture of $\mathrm{P}$. alata were not observed in this work.
\end{abstract}

Key words: Passiflora alata, $\beta$-carboline alkaloids, pyrazoles, callus culture

\section{INTRODUCTION}

Leaves from several Passiflora (vernacular passionflower) lianoid species are widely used in folk medicine as anxiolytics and sedatives. Since 1867, they have formed part of classical medicine as sedatives, and to combat the sleeplessness and irritability (Freitas, 1985). The leaves of Passiflora alata Curtis, Passifloraceae ("sweet passion fruit") are registered in three editions of the Brazilian Pharmacopoeia. Despite being formally registered, studies focusing on the chemistry of this species are scarce, making the standardization of this traditional drug difficult. $P$. incarnata $\mathrm{L}$. has been extensively studied, both chemically and biologically, and is included in the European Pharmacopoea (Dhawan et al., 2001 and 2004; Soulimani et al., 1997). The biological activity of other Passiflora species has been investigated, such as $P$. actinia (Santos et al., 2006) and $P$. edulis (Rebello et al., 2007). The principal bioactive compounds described in

*Author for correspondence: maique@ccs.ufsc.br 
this genus are $C$-glycosyl derivatives of apigenin and luteolin (vitexin, isovitexin, orientin, isoorientin, and schaftoside, among others), constituting the best currently available options as quality markers (Schmidt and González-Ortega, 1993; Petry et al., 1998). Recently, an aqueous extract of $P$. edulis presented anxiolytic-like activity without any significant effect on motor activity, whilst the total flavonoid fraction (which contains luteolin-7-O-[2-rhamnosylglucoside]) presented an anxiolytic-like activity but compromised motor activity (Coleta et al., 2006).

Although several in vivo experiments have been carried out to determine more precisely the pharmacological activity of Passiflora, it is not yet possible to attribute the overall effects of this species to any single class of compounds or entity (Pereira and Vilegas, 2000; de Paris et al., 2001; Abourashed et al., 2002). The possible concerted action of several alkaloids and flavonoids in producing therapeutic effects of the Passiflora drug has been emphasized (Benatti, 1971). Some early reports indicate harmane alkaloids as the main bioactive constituents of $P$. incarnata, due to their MAO enzyme inhibiting properties (Dhawan et al., 2001, 2004; Soulimani et al., 1997).

Harmane alkaloids were described in the genus Passiflora in the 1950s, and its biosynthesis from $L$-tryptophan has been proposed (Slaytor and McFarlane, 1968). In the 1970s and earlier, analytical works carried out using less sensitive techniques found appreciable amounts of alkaloids in the genus Passiflora (Lutomski et al., 1974, 1975; Lutomski and Malek, 1975; Benatti 1967, Poethke et al., 1970, Neu 1956, 1954). However, recent studies by HPLC have not indicated the presence of harmane alkaloids in this genus (Rehwald et al., 1995, Grice et al., 2001, Abourashed et al., 2003). Only one work describing $\beta$-carboline alkaloids in large amounts in P. incarnata, by HPLC, was found (Tsuchiya et al., 1999). Some authors have linked the presence of these alkaloids with the developmental stage of the plant (Bisset and Wichtl, 2001). There were insufficient data to determine whether alkaloid profiles could be influenced by genotypes.

A previous work on $P$. alata leaves conducted in our laboratory failed to detect harmane alkaloids by HPLC analysis, which prompted us to investigate the production of this type of compound by plant cell cultures, inducing its biosynthesis through precursor feeding, which has been one of the most successful ways of inducing secondary metabolism in cell cultures (Hughes and Shanks, 2002). However, the production of in vitro compounds in Passiflora has never been investigated. Therefore, this work dealt with inducing the callus and cell culture of P. alata and the investigation of in vitro alkaloid production, with and without $L$-tryptophan feeding.

The cell culture of Passiflora was revised (Drew 1997), and some authors, using several explants such as endosperm and zygotic embryo (Guzzo et al., 2004), internode segments (Biasi et al., 2000) and leaf discs (Monteiro et al., 2000) carried out organogenesis. The culture of isolated protoplasts (naked cells), followed by reproducible plant regeneration, was also studied (Davey et al., 2006).

\section{MATERIALS AND METHODS}

\section{Plant material and tissue culture conditions}

Callus cultures were established from $P$. alata leaves, obtained from authentic matrixes, from the Empresa de Pesquisa Agropecuária e Extensão Rural de Santa Catarina (Epagri) - Estação Experimental de Itajaí. Leaf fragments from mature leaves were washed in distilled water and neutral detergent $(2 \mathrm{~min})$, followed by immersion in $5 \% \mathrm{Ca}(\mathrm{OC} 1)_{2}$ solution $(10 \mathrm{~min})$. These were then washed in distilled water again, and then in $\mathrm{EtOH} 70 \%(1 \mathrm{~min})$, sterilized in $0.3 \% \mathrm{HgCl}$ solution $(5 \mathrm{~min}$ ), and rinsed three times with sterile distilled water. The leaf fragments were placed on a MS (Murashige-Skoog) medium with sucrose $(30 \mathrm{~g} / \mathrm{L})$ and agar $(7 \mathrm{~g} / \mathrm{L})$ and $\mathrm{pH}$ adjusted to $\cong 5.8$. The media were supplemented with benzylaminopurine (BAP) (3 $\mathrm{mg} / \mathrm{L}), \quad 2,4-$ dichlorphenoxyacetic (2,4-D) $(2 \mathrm{mg} / \mathrm{L})$, and kinetin (KIN) (3 $\mathrm{mg} / \mathrm{L})$ - the optimized phytohormone combination, previously determined (unpublished data). Cultures were carried out under aseptic conditions and incubated at $28^{\circ} \pm 1^{\circ} \mathrm{C}$ with $16 \mathrm{~h}$ photoperiods at $40-50$ $\mu \mathrm{mol} / \mathrm{m}^{2} / \mathrm{s}$. Calli were subcultured ( $1 \mathrm{~g}$, fresh weight) every four weeks to the same supplemented media described above, with and without $L$-tryptophan (50, 100, and $200 \mathrm{mg} / \mathrm{L}$ ). Calli were collected on days 6, 16, 26, 36, and 90 . 
Extraction, isolation and analysis of the secondary metabolites

After the incubation period, the calli were purged and dried at $50^{\circ} \mathrm{C}$ for $24 \mathrm{~h}$, homogenized in an ultrasonic bath for 15 min with $2 \% \mathrm{HCl}$, and then filtered. This procedure was repeated three times, and the resulting extracts were combined. Next, the $\mathrm{pH}$ was increased $(\mathrm{pH} \sim 10)$ by the addition of $\mathrm{NH}_{4} \mathrm{OH}$ and extracted with $\mathrm{CH}_{2} \mathrm{Cl}_{2}(3 \times 20 \mathrm{~mL})$. The combined organic extracts were washed with $\mathrm{H}_{2} \mathrm{O}(3 \times 20 \mathrm{~mL})$, dried with $\mathrm{Na}_{2} \mathrm{SO}_{4}$, filtered and submitted to solvent elimination under reduced pressure, on a rotary evaporator.

TLC investigation of the extracts was carried out using toluene/ethyl acetate/diethylamine (70:20:10 $\mathrm{v} / \mathrm{v})$ as mobile phase and Sorbent Silica gel $\mathrm{F}_{254}$ as stationary phase, revealing the presence of the metabolites under UV light at 254 and $365 \mathrm{~nm}$. The extracts were, therefore, redissolved in $\mathrm{MeOH}$ (HPLC grade) (1:10 w/v) and submitted to HPLC analysis, as well as MeOD- $d_{4}$ for NMR measurements. The peaks eluted from the HPLC analysis were collected, and the mobile phase was eliminated using a speed-vac system, prior to MS analysis.

\section{HPLC analysis}

The HPLC system consisted of a Waters 600 pump, a 2996 PDA detector, and a Rheodyne 7725i (loop $20 \mu \mathrm{L}$ ) manual injector. The analyses were carried out on a Phenomenex Synergi RP-18 ( $250 \times 4.6 \mathrm{~mm}$ i.d., $5 \mu \mathrm{m})$ column, inside a column oven fit to $30{ }^{\circ} \mathrm{C}$. The mobile phase was $\mathrm{MeOH} / \mathrm{NaOAc}(50 \mathrm{mM}, \mathrm{pH} 4.0)$ in a linear gradient mode from 30 to $100 \%$ of $\mathrm{MeOH}$ in 25 min, maintained for $5 \mathrm{~min}$, and reaching the initial composition in $10 \mathrm{~min}$. The flow rate was 1.0 $\mathrm{mL} / \mathrm{min}$. The analyses were monitored at 250 and $340 \mathrm{~nm}$. All the organic solvents were HPLC grade, and the ultra pure water (Milli-Q system, Millipore) was filtered through $0.45 \mu \mathrm{m}$ membranes (regenerate cellulose, Schleicher and Schuell) and degassed prior to use. Commercial $\beta$ carboline alkaloid samples (harmane, harmine, harmol, harmalol, and harmaline, from Spectrum) were used as standards.

\section{Spectrometric analysis}

MS experiments were performed on a hybrid triple quadrupole/linear ion trap mass spectrometer (4000 Q-Trap system, Applied Biosystems), equipped with a turbo ion spray, source with injection flux of $10 \mu \mathrm{L} / \mathrm{min}$; and a sample of 1 $\mathrm{mg} / \mathrm{mL} \mathrm{MeOH} / \mathrm{H}_{2} \mathrm{O} 50 \%$ (v/v) were introduced. The ion spray voltage was 5500 was $\mathrm{V}$ and the heated interface plate was set to $100^{\circ} \mathrm{C}$. Nitrogen was used as curtain (value of 50) and collision gas (set to high). Source gases 1 and 2 were set to 50 and 30, respectively. The desclustering potential was $50 \mathrm{~V}$ and the collision energy was $15 \mathrm{eV}$. The mass detection was performed in positive ion mode using an Electrospray probe. EP (entrance potential $)=5$.

NMR spectra were recorded at $293 \mathrm{~K}$ in MeOD- $\mathrm{d}_{4}$ on a Bruker AVANCE 400 NMR spectrometer operating at 9.4 Tesla, observing ${ }^{1} \mathrm{H}$ at 400.13 $\mathrm{MHz}$.

\section{RESULTS AND DISCUSSION}

In vitro propagation of Passiflora has shown high contamination levels and difficulty in breaking the dormancy of the seeds (Monteiro et al., 2000, Passos et al., 2004). Therefore, in this work, the seeds of $P$. alata were treated with gibberellic acid after disinfection, and presented low germination levels (less than 5\%). The leaf explants presented more satisfactory results after disinfection, and the callus formation was initiated 30 days after inoculation; dedifferentiation was observed on the cut surface of the leaf explants, and this material was sub-cultured 60 days after induction. These calli ( $1 \mathrm{~g}$, cream in colour) without morphological differentiation, were inoculated in semi-solid MS media $(20 \mathrm{~mL})$ with and without the addition of $L$ tryptophan $(50,100,200 \mathrm{mg} / \mathrm{L})$, and kept in standard conditions for 90 days. Samples were collected on days $6,16,26,36$, and 90 , using an acid-base extraction, and submitted to HPLC analysis. During this period, the cultures preserved their initial aspect, with slight growth of cellular mass. The results of the evaluation of the main metabolites found in the organic extracts from the in vitro cultures showed an absence of the selected $\beta$-carboline alkaloids. Figure 1 shows the chromatogram profile of the selected standards, harmalol, harmol, harmane, harmaline, and harmine, as well as their UV profiles. These alkaloids were not observed through retention time and UV spectra in any of the samples analyzed. Some authors dealing with $L$-tryptophan addition and harmane alkaloid production observed an increase in harmaline and harmine (Pinto and 
Lameira, 2004) in Peganum harmala L., Zygophyllaceae callus culture. Without $L$ tryptophan addition, serotonin was also detected in this species (Sasse et al, 1982). Supplementation with 2,4-D and KIN stimulated harmol and harmalol synthesis in Coptis japonica Makino, Ranunculaceae (Pinto and Lameira, 2004).

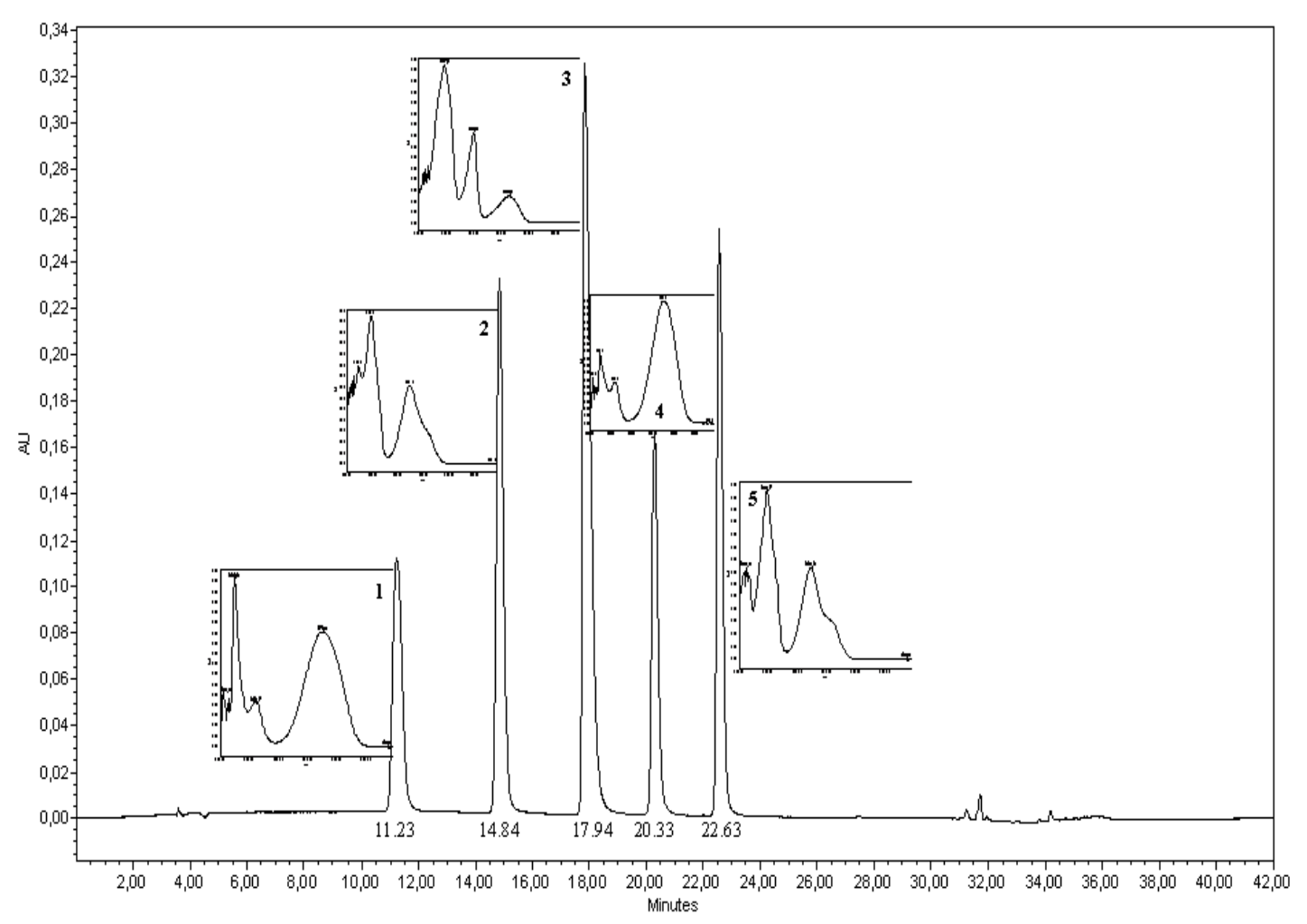

Figure 1 - Chromatogram of standard $\beta$-carboline alkaloids $(100 \mu \mathrm{g} / \mathrm{mL}), 340 \mathrm{~nm}$. Peaks 1-5 correspond to harmalol, harmol, harmane, harmaline and harmine, respectively. For chromatographic conditions, see Material and Methods.

With $L$-tryptophan feeding, independent of cultivation time or amount added, two peaks (A and $\mathrm{B})$ were consistently detected in the extract produced, with different UV profiles and retention times (17.30 min, A and $22.96 \mathrm{~min}, \mathrm{~B})$ from the standards used (Fig. 2). All the L-tryptophan concentrations presented the same peaks, with relative areas in different proportions for each concentration tested. Calli cultivated without the addition of $L$-tryptophan did not present peaks in the selected eluent system in the time studied.

The same organic extract which was analysed by HPLC crystallized in a refrigerator and the ${ }^{1} \mathrm{H}$ NMR spectrum was obtained for the resulting crystals, showing overlapping signals only in the aromatic region ( $\delta 7.0$ to $9.0 \mathrm{ppm})$. As for the $\beta$ carboline standards, TLC analysis of the extracts presented fluorescent zones. Due to the small quantity of sample, the peaks (A and B) eluted by
HPLC analysis, were collected and analyzed through positive-mode Electrospray[ESI(+)-MS] and sequential analysis in tandem ESI(+)-MS/MS, using a triple quadrupole combined with an iontrap linear device. The spectra obtained (full scan) from A and B were very similar, with repetition of the more intense ions. The sequential analyses (MS/MS) of ions $\mathrm{m} / \mathrm{z} 431$ and $\mathrm{m} / \mathrm{z} 227$ were fragmented through collision with nitrogen inside a collision chamber $(\mathrm{Q} 2)$.

The fragmentation of the ion $m / z 431$ of $\mathrm{B}$, resulted in daughter ions of $\mathrm{m} / \mathrm{z} 362, \mathrm{~m} / \mathrm{z} 295, \mathrm{~m} / \mathrm{z}$ 227 (more intense), $m / z 158$ and $m / z 91$ (Fig. 3). From these results, it could be clearly seen that ion $\mathrm{m} / \mathrm{z} 227$ was a fragment formed from ion $\mathrm{m} / \mathrm{z} 431$.

From A, the spectrum ESI(+)-MS/MS of ion $\mathrm{m} / \mathrm{z}$ 227 was obtained, which presented mainly the ions $\mathrm{m} / z 159$ and $\mathrm{m} / \mathrm{z} 91$ (Fig. 4), just as observed for the MS fragmentation of ion $\mathrm{m} / z 431$ from the $\mathrm{B}$. 


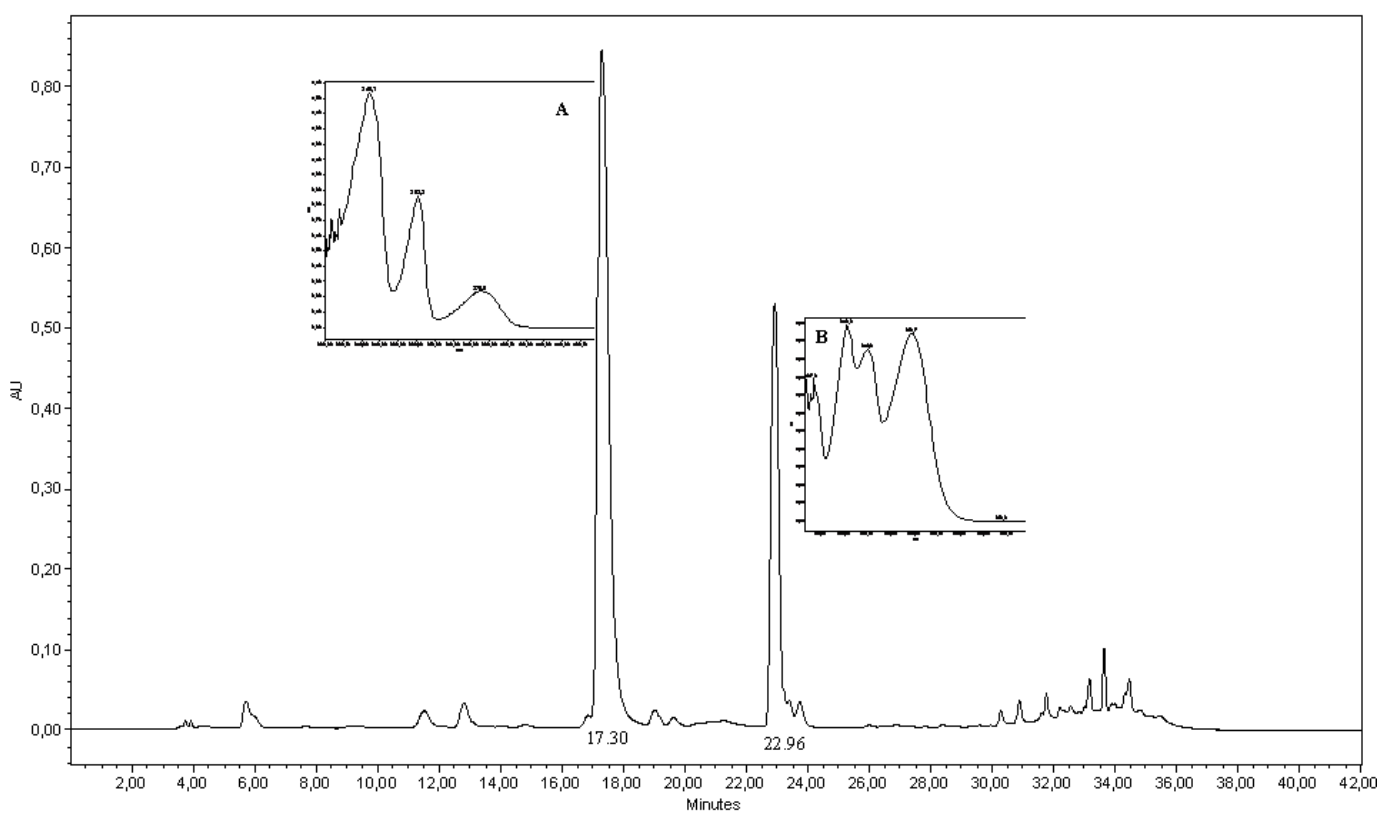

Figure 2 - Chromatogram of concentrated calli extracts, $300 \mathrm{~nm}$. For chromatographic conditions, see Material and Methods.

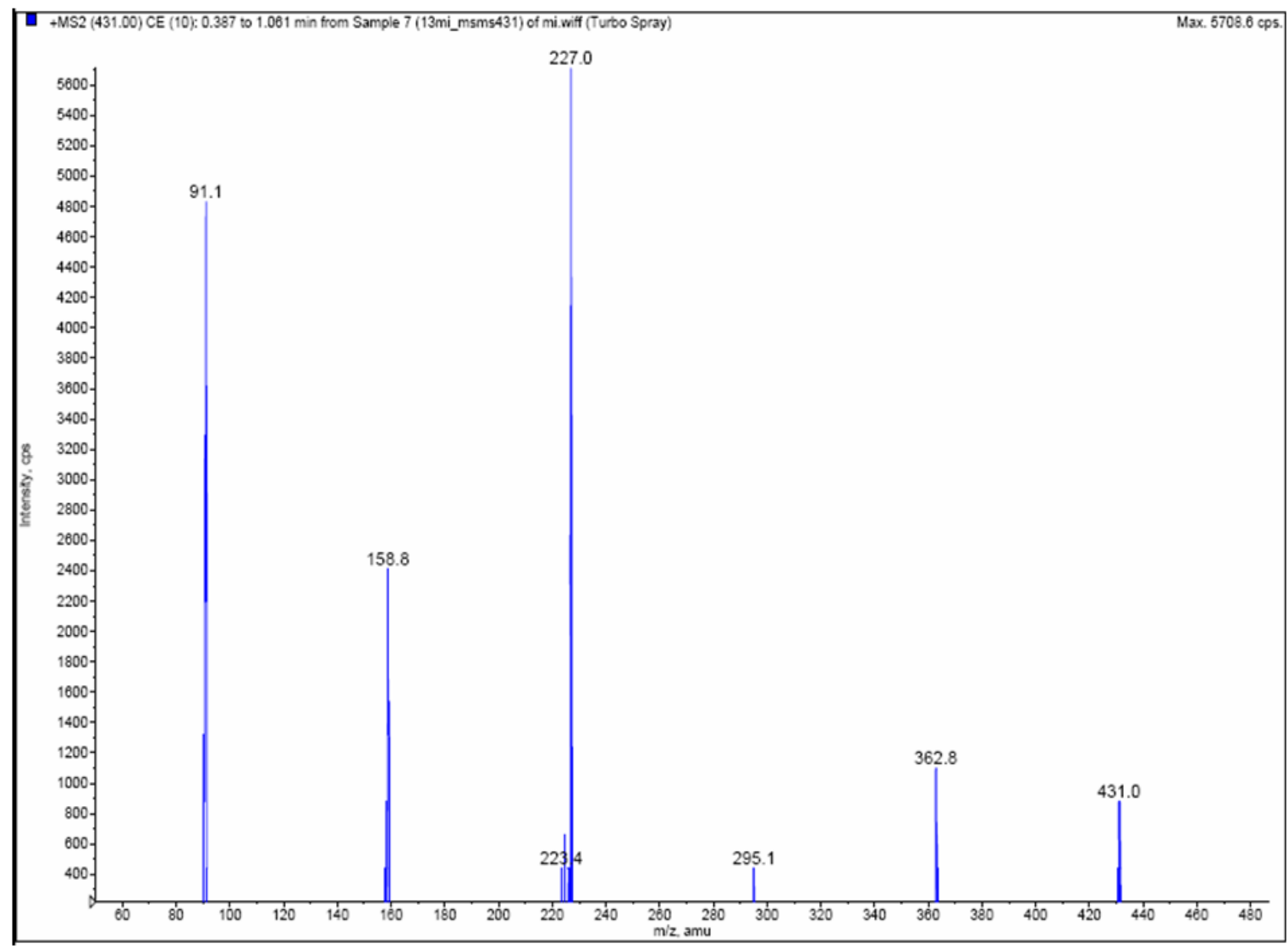

Figure 3 - Spectrum ESI (+)-MS/MS of ion $m / z 431$ from B. For analytical details, see Material and Methods. 


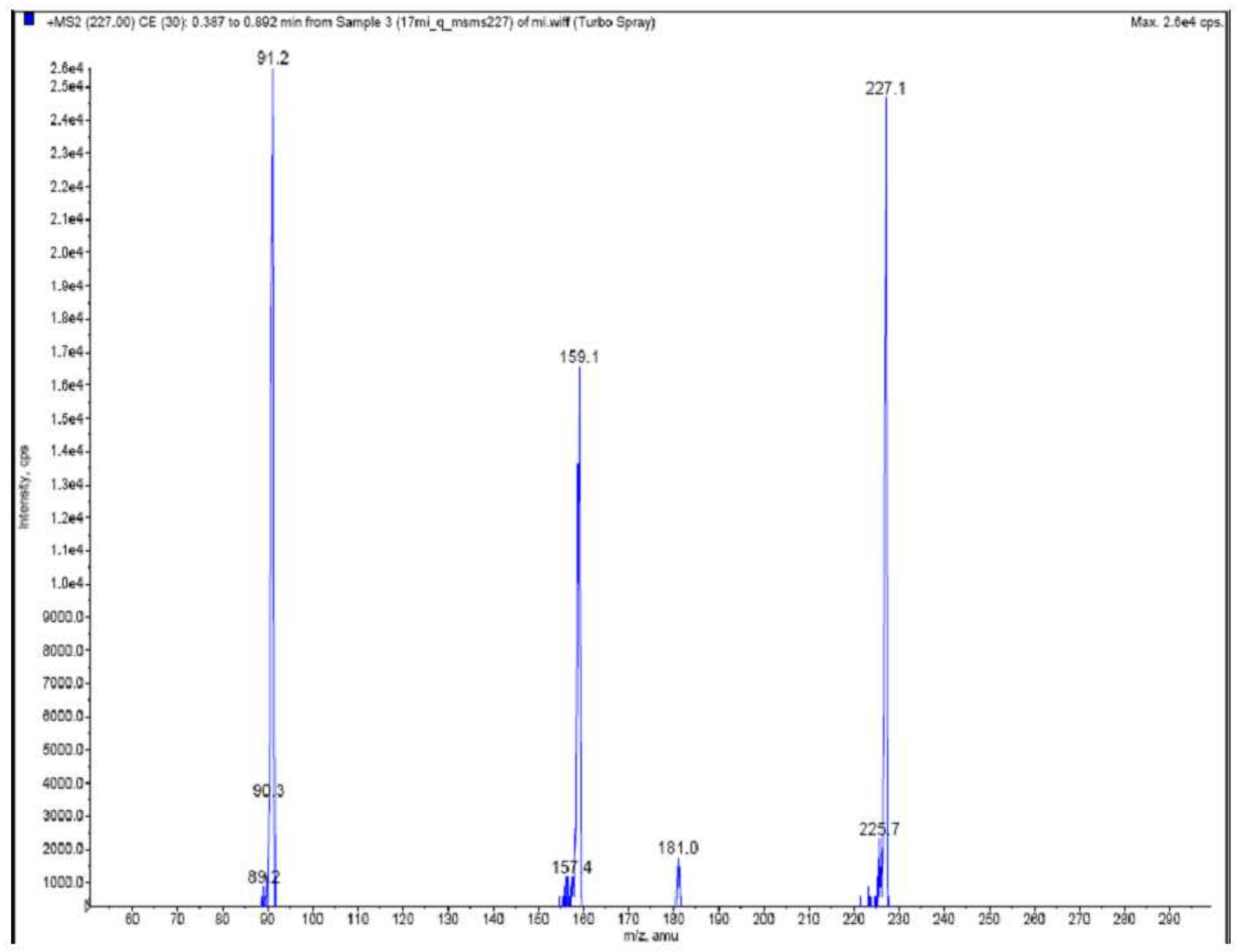

Figure 4 - Spectrum ESI(+)-MS/MS of ion $m / z 227$ from A. For analytical details, see Material and Methods.

From the ESI(+)-MS/MS spectrum of ion $\mathrm{m} / \mathrm{z} 431$ and $\mathrm{m} / \mathrm{z} 227$, the consecutive loss of $68 \mathrm{Da}$ units could be observed. This neutral unit was attributed to the heterocycle pyrazole, according to the fragmentation proposal presented in Figure 5.

According to these results, it could be concluded that the $L$-tryptophan indole ring was opened, followed by a rearrangement, giving the product (pyrazole). Apparently, this transformation was not related to any enzymatic pathway previously described for plant biosynthesis from $L$ tryptophan, since all the metabolites formed kept the indole ring intact. However, the formation of heterocycle rings is frequently observed in processes mediated by heating (pyrolysis), from amino acids and reducing sugars (Maria et al., 1999). The nonenzymatic reaction of a reducing sugar and the free amino groups of a protein or peptide is called the Maillard reaction (MR), and is one of the most important phenomena that occur during the processing, cooking, and storage of foods. Numerous studies have reported some beneficial effects associated with the Maillard reaction products (MRPs), including the formation of compounds with antioxidant anticarcinogenic, and antimutagenic properties (Sun et al., 2007). Many studies have focused on the high antioxidant capacity of MRPs in model systems and foods such as beer, coffee and baked products. The majority of studies consider MR as a series of subsequent and parallel reactions. Although pyrazoles are not considered common MRPs, their presence was evidenced in Maillard systems, indicating the diversity of molecular structures that could be formed during the reaction (Yaylayan and Haffenden, 2003).

In order to test the hypothesis that the pyrazoles obtained here could be MRPs, a mixture consisting 
of $L$-tryptophan and sucrose in water (in the same proportion as that used for the MS media) was processed in the same way as calli $\left(50{ }^{\circ} \mathrm{C}, 24 \mathrm{~h}\right)$, extracted, and injected in HPLC. Surprisingly, the same peaks (minute amounts), with the same retention time and UV profile, together with other unknown peaks, were observed in the chromatogram (Fig. 6).
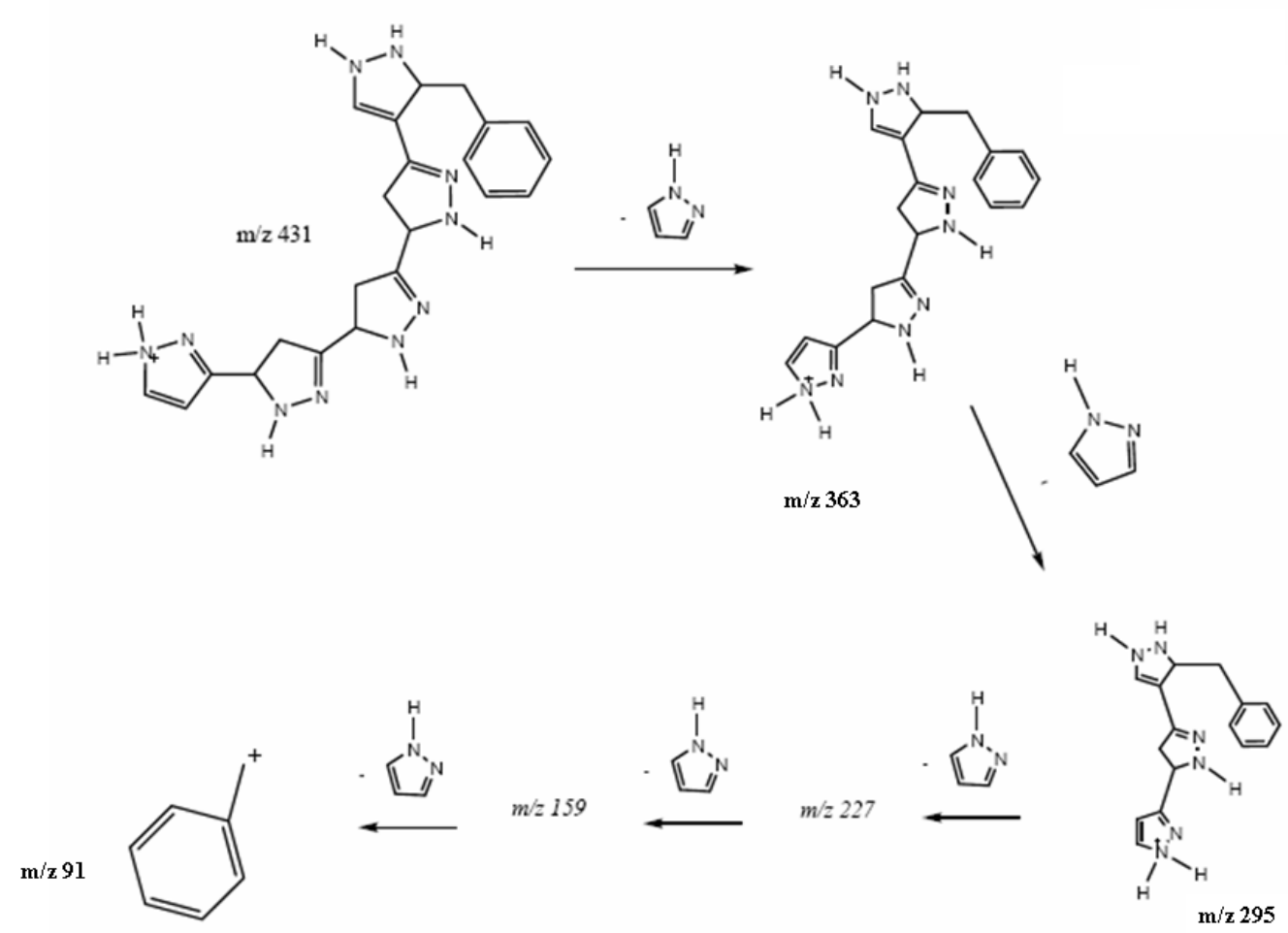

Figure 5 - Fragmentation proposition for substances present in the calli extract of $P$. alata.

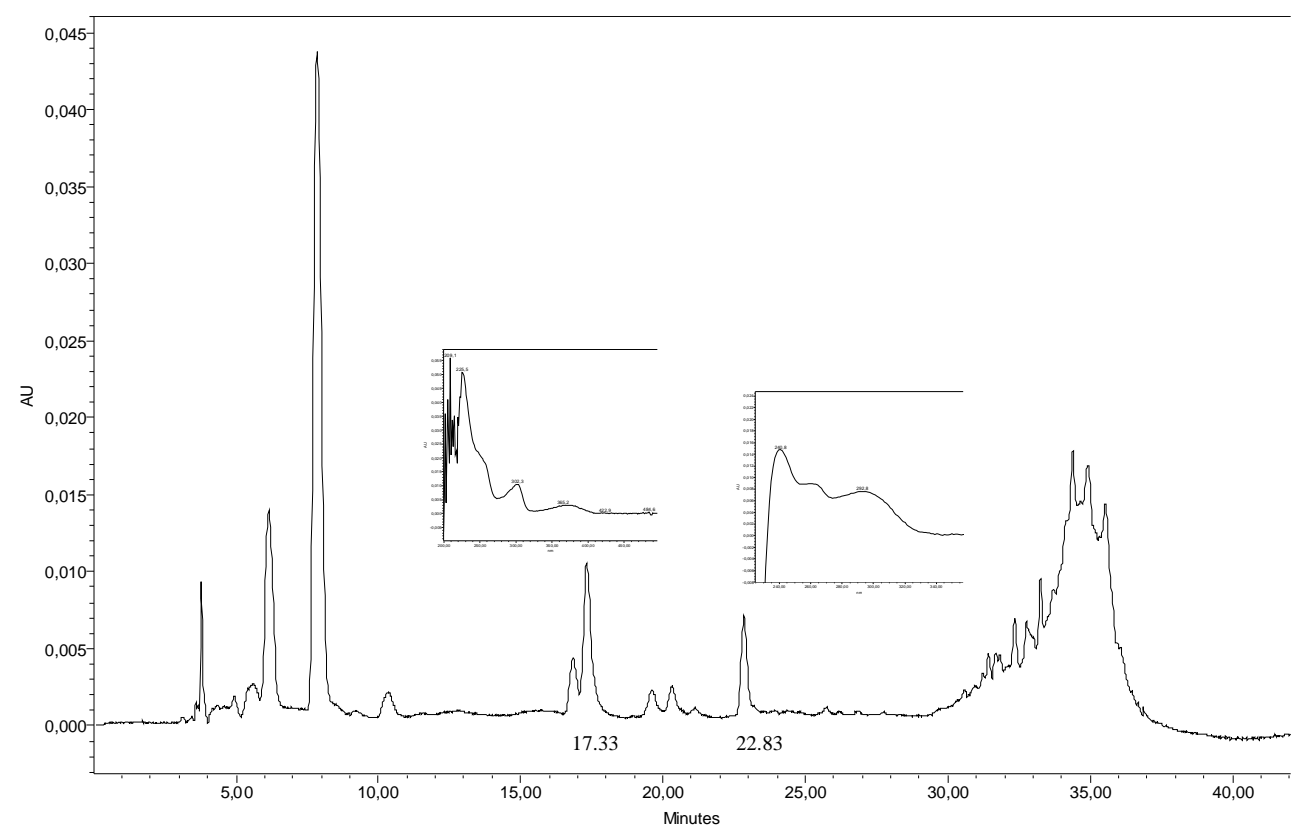

Figure 6 - Chromatogram of sucrose and $L$-tryptophan mixture, $300 \mathrm{~nm}$. For chromatographic conditions, see Material and Methods. 
Therefore, $L$-tryptophan feeding on MS media did not influence the biosynthesis of $\beta$-carboline alkaloids in callus culture of $P$. alata. Despite considerable efforts to produce the secondary metabolites by undifferentiated plant cell cultures, it has become increasingly apparent that the presence of a degree of morphological organization greatly enhances the likelihood of the formation of successful alkaloids in vitro (Pasquali et al., 2006).

\section{ACKNOWLEDGEMENTS}

Authors thank Univali and Epagri for providing the physical facilities and technical support.

\section{RESUMO}

As folhas de varias espécies de Passiflora são utilizadas como ansioliticas e sedativas. Passiflora alata Curtis, Passifloraceae consta em três edições da farmacopéia brasileira, porem não há muitos estudos sobre sua composição química. No passado, enfatizava-se a ação conjunta de alcalóides e flavonóides. Em trabalho anterior, não foi detectada a presença de alcalóides harmanicos através de CLAE. Assim, decidiu-se investigar a produção dos mesmos através de cultivo celular, introduzindo seu precursor metabólico Ltriptofano.

Os explantes foliares apresentaram resultados satisfatorios para germinação apos assepsia, e a formação de calo foi iniciada em meio MS com quantidades adequadas de fitohormonios, previamente determinadas. Sessenta dias após a inoculação os calos foram repicados para meio semi-solido com e sem L-triptofano (50, 100, 200 $\mathrm{mg} / \mathrm{L})$, mantidos por 90 dias em condições padrão. Amostras foram coletadas com 6, 16, 26, 36, e 90 dias, realizada extração acido-base e o extrato analisado por CLAE. Os resultados mostraram a ausência de harmana, harmina, harmol, harmalol e harmalina. Dois picos presentes nas amostras com L-triptofano foram coletados e analisados através de espectrometria de massas, electrospray modo positiva $[\operatorname{ESI}(+)-\mathrm{MS}]$ e analise em tandem $\operatorname{ESI}(+)$ MS/MS. Os espectros correspondentes foram similares, mostrando a perda consecutiva de 68 $\mathrm{Da}$, atribuídos ao pirazol. Este fato aponta para uma transformação não enzimática, não relacionada a uma biossintese previamente descrita para alcalóides $\beta$-carbolínicos.

\section{REFERENCES}

Abourashed, E. A., Vanderplank, J. R., Khan, I. A. (2002), High-speed extraction and HPLC fingerprinting of medicinal plants - I. Application to Passiflora flavonoids. Pharm. Biol., 40, 81-91.

Abourashed, E. A., Vanderplank, J., Khan, I. A. (2003), High-Speed Extraction and HPLC Fingerprinting of Medicinal Plants - II. Application to Harmane Alkaloids of Genus Passiflora. Pharm. Biol., 41, 100106.

Benatti, E. (1967), Riconoscimento per cromatografia su strato sottile dell'estratto fluido di Passiflora incarnata. Boll. Chim. Farm., 106, 756-760.

Benatti, E. (1971), Quantitative determination of harmanee and harmine in the extract of Passiflora incarnata. Boll. Chim. Farm., 110, 664-669.

Biasi, L. A., Falco, M. C., Rodriguez, A. P. M., Mendes, B. M. J. (2000), Organogenesis from internodal segments of yellow passion fruit. Sci. Agric., 57, 661-665.

Bisset, N. G., Wichtl, M. (2001), Herbal drugs and phytopharmaceuticals: a handbook for practice on a scientific basis with reference to German Commission and Monographs. 2 ed., Medpharm Scientific, Stuttgart.

Coleta, M., Batista, M. T., Campos, M. G., Carvalho, R., Cotrim, M. D., Lima, T. C., Cunha, A. P. (2006), Neuropharmacological evaluation of the putative anxiolytic effects of Passiflora edulis Sims, its subfractions and flavonoid constituents. Phytother. Res., 20, 1067-1073.

Davey, M. R., Anthony, P., Power, J. B., Lowe, K. C. (2006), Isolation, culture, and plant regeneration from leaf protoplasts of Passiflora. Methods Mol. Biol., 318, 201-210.

Dhawan, K., Kumar, S., Sharma, A. (2001), Antianxiety studies on extracts of Passiflora incarnata Linneaus. J. Ethnopharmacol., 78, 165-170.

Dhawan, K., Dhawan, S., Sharma, A. (2004), Passiflora, a review update. J. Ethnopharmacol., 94, 1-23.

De-Paris, F., Petry, R. D., Reginatto, F. H., Gosmann, G., Quevedo, J., Salgueiro, J. B., Kapczinki, F., Ortega, G. G., Schenkel, E. P. (2001), Pharmacochemical study of aqueous extracts of Passiflora alata Dryander and Passiflora edulis Sims. Acta Farm. Bonaerense., 21, 5-8.

Drew, R. A. (1997), Micropropagation of Passiflora species (Passionfruit). In-High-tech and micropropagation V. ed. Y. P. S. Bajaj, SpringerVerlag, Berlin, pp. 135-149. 
Freitas, P. C. D. (1985), Estudo farmacognóstico comparativo de espécies brasileiras do gênero Passiflora L. Master Thesis, Universidade de São Paulo, São Paulo, Brazil.

Grice, I. D., Ferreira, L. A., Griffiths, L. R. (2001), Identification and simultaneous analysis of harmane, harmine, harmol, isovitexin, and vitexin in Passiflora incarnata extracts with a novel HPLC method. $J$. $L$. Chrom. and Rel. Technol., 24, 2512-2523.

Guzzo, F., Ceoldo, S., Andreatta, F., Levi, M. (2004), In vitro culture from mature seeds of Passiflora species. Sci. Agric., 61, 108-113.

Hughes, E. A., Shanks, J. V. (2002), Metabolic Engineering of Plants for Alkaloid Production. Metab. Eng., 4, 41-48.

Lutomski, J., Malek, B., Stachowiak, Z. (1974), Pharmacochemical investigation of the raw materials from Passiflora genus, new method of chromatographic separation and fluorometricplanimetric determination of alkaloids and flavonoids in harmane raw materials. Planta Med., 26, 311-317.

Lutomski, J., Malek, B. (1975), Pharmacochemical investigations on raw materials genus passiflora. 3 . Phytochemical investigations on raw materials of Passiflora edulis forma flavicarpa. Planta Med., 27, 222-225.

Lutomski, J., Malek, B., Rybacka, L. (1975), Pharmacochemical investigations of the raw materials from passiflora genus. 2. The pharmacochemical estimation of juices from the fruits of Passiflora edulis and Passiflora edulis forma flavicarpa. Planta Med., 27, 112-121.

Maria, C. A., Moreira, R. F. A., Trugo, L. C. (1999), Componentes voláteis do café torrado. Parte I, compostos heterocíclicos. Quim. Nova, 22, 209-217.

Monteiro, A. C. B. A., Nakazawa, G. T., Mendes, B. M. J., Rodriguez, A. P. M. (2000), Regeneração in vitro de Passiflora suberosa a partir de discos foliares. Sci. Agric., 57, 571-573.

Neu, R. (1954), The constituents of Passiflora incarnata. II. Basic components. Arzneimittelforschung., 4, 601-606.

Neu, R. (1956), Composition of Passiflora incarnata. III. The alkaloid of Passiflora, 3-methyl-4-carbolin (2'-methyl-(pyridino-3', 4', 2,3-indole)] Arzneimittelforschung., 6, 94-98.

Pasquali, G., Porto, G. D., Fett-Neto, A. G. (2006), Metabolic engineering of cell cultures versus whole plant complexity in production of bioactive monoterpene indole alkaloids, Recent progress related to old dilemma. J. Biosci. Bioeng., 101, $287-$ 296.
Passos, I. R. S., Matos, G. V. C., Meletti, L. M. M., Soares-Scott, M. D., Bernacci, L. C., Vieira, M. A. R. (2004), Utilização do ácido giberélico para a quebra de dormência de sementes de Passiflora nitida Kunth germinadas in vitro. Rev. Bras. Frutic., 26, 380-381.

Pereira, C. A. M., Vilegas, J. H. Y. (2000), Constituintes químicos e farmacologia do gênero Passiflora com ênfase a $P$. alata Dryander, $P$. edulis Sims e P. incarnata L. Rev. Bras. Plantas Med., 3, 112.

Petry, R. D., de Souza, K. C. B., Basani, V. L., Petrovick, P. R., González-Ortega, G. (1998), Doseamento do teor de flavonoides totais em extratos hidroalcoolicos de Passiflora alata Dryander (maracujá) Rev. Bras. Farm., 79, 7-10.

Pinto, J. E. P., Lameira, A. O. (2004), Micropropagação e Metabolitos Secundários in vitro de Plantas Medicinais. Editora UFLa - Universidade Federal de Lavras, Lavras, pp. 75-86.

Poethke, W., Schwarz, C., Gerlach, H. (1970), Contents of Passiflora bryonioides. 1. Alkaloids. Planta Med., 18, 303-314.

Rebello, B. M., Moreno, S. R. F., Godinho, C., Neves, R. F., Fonseca, A. S., Caldas, L. Q. A., BernardoFilho, M., Medeiros, A. C. (2007), Effect of a peel passion fruit flour (Passiflora edulis f. flavicarpa) extract on the labeling of blood constituents with technetium-99m and on the morphology of red blood cells. Braz. Arch. Biol. Technol., 50, 153-159.

Rehwald, A., Meier, B., Sticher, O. (1995), Trace analysis of Harmane alkaloids in Passiflora incarnata by reversed high performance liquid chromatography. Phytochem. Anal., 6, 96-100.

Santos, K. C., Kurtz, S. M. T. F., Müller, S. D., Biavatti, M. W., Oliveira, R. M. M. W., Santos, C. A. M. (2006), Sedative and anxiolytic effects of methanolic extract from the leaves of Passiflora actinia. Braz. Arch. Biol. Technol., 49, 565-573.

Sasse, F., Heckenberg, U., Berlin, J. (1982), Accumulation of b-carboline alkaloids and serotonin by cell cultures of Peganum harmala L. Plant Physiol., 69, 400-404.

Schmidt, P. C., González-Ortega, G. (1993), Passionsblumenkraut Bestimmung des Gesamtflavonoidgehaltes von Passiflorae herba. Dtsch. Apoth-Ztg., 133, 4457-4466.

Slaytor, M., McFarlane, I. J. (1968), The biosynthesis and metabolism of harmane in Passiflora edulis-I, The biosynthesis of harmane. Phytochemistry., 7, 605-611. 
Soulimani, R., Younos, C., Jarmouni, S., Bousta, D., Misslin, R., Mortier, F. (1997), Behavioural effects of Passiflora incarnata L. and its indole alkaloid and flavonoid derivatives and maltol in the mouse. $J$. Ethnopharmacol., 57, 11-20.

Sun, Y., Hayakawa, S., Ogawa, M., Izumori, K. (2007), Antioxidant properties of custard pudding dessert containing rare hexose, D-psicose. Food Control., 18, 220-227.
Tsuchiya, H., Shimizu, H., Iinuma, M. (1999), BetaCarboline Alkaloids in Crude Drugs. Chem. Pharm. Bull., 3, 440-443.

Yaylayan, V. A., Haffenden, L. J. W. (2003), Mechanism of pyrazole formation in [13C-2] labeled glycine model systems, N-N bond formation during Maillard reaction. Food Res. Int., 36, 571-577.

Received: January 17, 2008; Revised: November 17, 2008; Accepted: October 27, 2009. 